\title{
Effects of water quality on cattle performance
}

\author{
WALTER D. WILLMS, ORIN R. KENZIE, TIM A. MCALLISTER, DOUG COLWELL, DOUG VEIRA, JOHN F. \\ WILMSHURST, TOBY ENTZ, AND MERLE E. OLSON
}

Authors are Range Ecologist, Agriculture and Agri-Food Canada, PO Box 3000, Lethbridge, Alberta, Canada T1J 4B1; Intensive Livestock-Siting Specialist, Alberta Agriculture Food and rural Development, Lethbridge; Rumen Microbiologist and Livestock Parasitologist, Agriculture and Agri-Food Canada, Lethbridge; ruminant nutritionist, Agriculture and Agri-Food Canada, Kamloops, British Columbia; Range Ecologist, Parks Canada, Winnipeg, Manitoba, Statistician, Agriculture and Agri-Food Canada. Lethbridge; and Gastrointestinal Researcher, University of Calgary, Calgary, Alberta.

\begin{abstract}
Water is an important nutrient for livestock production and is often provided on rangelands directly from ponds or dugouts. Cattle may defecate and urinate into the water thereby adding nutrients and reducing palatability. A study was conducted to examine the effects of water source on cattle production and behavior, to determine the relationship of selected chemical and biological constituents on the observed response and to test the effect of fecal contamination on water consumption. Four dugouts or ponds were selected at 4 sites: 2 in the Fescue Prairie near Stavely in southwestern Alberta, 1 in the Mixed Prairie at Onefour in southeastern Alberta, and 1 in the Palouse Prairie near Kamloops, British Columbia. Yearling Herefords were tested at 3 sites and Hereford cow-calf pairs at 1 Stavely site. At each site, three paddocks radiated from the pond that were stocked with 10 yearlings or cow-calf pairs randomly assigned to either clean water (water delivered to a trough from a well, river, or pond), pond water pumped to a trough (pond trough $_{1}$ ), or direct access into the pond (pond direct ). The trials were repeated at each site for 3 to 6 years. Observations were made on cattle weight gains, cow backfat thickness, and activity budgets. Fecal samples were analyzed for selected parasites and pathogens. Other experiments were conducted to determine the effects of manure-contaminated water on feed and water consumption and water selection. Calves, with cows drinking clean water, gained $9 \%$ more $(P$ $<0.10$ ) weight than those with cows on pond direct $_{\text {but cow weight }}$ and backfat thickness were not affected. Yearling heifers having access to clean water gained $23 \%(P=0.045)$ and $20 \%(P=$ $0.076)$ more weight than those on pond ${ }_{\text {direct }}$ and pond ${ }_{\text {trough, }}$ respectively. Cattle avoided water that was contaminated with $0.005 \%$ fresh manure by weight when given a choice of clean water. Cattle that had access to clean water spent more time grazing and less time resting than those that were offered pond $_{\text {trough }}$ or pond direct . Cattle management must consider water quality together with forage conditions in order to achieve optimal production from rangeland.
\end{abstract}

Key Words: ponds, dugouts, weight gains, water intake

The research was funded in part by the Waldron Grazing Association and Ducks Unlimited. The authors wish to thank Mr. Albert Middleton, Mr. Allan Ross, and Mr. Leo Stroesser for their help in managing the study sites. Mr. Ryan Beck was instrumental in collecting water and feces samples, collecting field data on cattle performance, and coordinating the yearly activities. The authors are also indebted to Mr. Bryan Farries who facilitated the work at Onefour and Stavely and to the Frolek Cattle Company of Kamloops, B.C. for providing the cattle and land for the Kamloops site.

Manuscript accepted 30 Dec. 01

\section{Resumen}

El agua es un nutriente importante para la producción ganadera y se provee a menudo directamente en los agostaderos de las charcas o de los aguajes. El ganado puede defecar y orinar en el agua y de ese modo agregar nutrientes y reducir la palatabilidad. Un estudio fue conducido utilizando ganado vacuno de la raza Hereford para examinar los efectos de la fuente de agua en la producción y el comportamiento del ganado, para determinar la relación de componentes químicos y biológicos seleccionados en la respuesta observada y para probar el efecto de la contaminación fecal en la consumición del agua. Cuatro aguajes o charcas (charca) fueron seleccionados en cuatro sitios: dos en la pradera de Festuca cerca de Stavely en el sudoeste de Alberta, uno en la pradera mixta en Onefour en el sudeste de Alberta y uno en la pradera de Palouse cerca de Kamloops en la Colombia Británica. Vaquillas de un año fueron utilizadas en tres sitios y pares de vacas con terneros en un sitio de Stavely. En cada sitio, tres potreros salieron en forma radiada de la charca conteniendo diez vaquillas de un año o diez vacas con terneros al pie, asignadas al azar al agua limpia (agua llevada a un bebedero de un pozo, un río, o una charca), agua de la charca bombeada a un bebedero (charca bebedero), 0 acceso directo a la charca (charca directo). Los estudios fueron repetidos en cada sitio de 3 a 6 años. Se realizaron observaciones de aumentos de peso del ganado, el espesor de la grasa del lomo de las vacas y vaquillas y el tiempo que pasaron en diferentes actividades. Fueron analizadas muestras fecales de parásitos y patógenos seleccionados. Otros estudios fueron conducidos para determinar los efectos del agua contaminada con abono en la consumición del pienso y del agua y la selección del agua. Los terneros, con las vacas bebiendo el agua limpia, ganaron un $9 \%$ más $(P<0.10)$ de peso que aquellos con las vacas en charca directo, pero el peso de las vacas y el espesor de la grasa del lomo no fueron afectados. Las vaquillas de un año que tenían acceso al agua limpia ganaron un $23 \%$ (P = $0.045)$ y un $20 \%(P=0.076)$ más de peso que aquellas en charca directo y charca bebedero, respectivamente. El ganado evitó el agua que estaba contaminada con $0.005 \%$ de abono fresco de peso cuando tenía acceso al agua limpia. El ganado que tenía acceso al agua limpia pasó más tiempo pastando y menos tiempo descansando que el que fue ofrecido el agua charca directo o el agua charca bebedero. Los administradores del ganado deben considerar la calidad del agua junto con las condiciones del forraje para lograr la producción óptima de la pradera. 
On rangeland, water for cattle is commonly derived from dugouts, ponds, or wells. Water quality is affected by its source and contamination from abiotic and biotic factors as a result of either dissolved nutrients or direct deposition of urine or fecal material containing nutrients and possibly parasites. Cattle are commonly hosts to Giardia spp., Cryptosporidium spp, nematodes and others parasites that affect their health. Giardiasis causes diarrhea in calves and lambs (Olson et al. 1995), C. parvum affects young calves (Olson et al. 1997a), and C. muris affects older animals (Anderson 1991). Water from deep wells or springs may have a high salt content if it originates from marine shales while dugouts and ponds are recharged mostly from surface water runoff or ground water that contains variable amounts of dissolved nutrients.

The effects of salt on cattle or sheep performance have been extensively studied. High salt content reduced sheep performance possibly by increasing osmolality of the rumen contents which suppressed feed intake (Barrio et al. 1991). Weeth and Capps (1972) reported no reduction in water intake by young cattle with $\mathrm{SO}_{4}$ levels up to 2,814 ppm added as $\mathrm{Na}_{2} \mathrm{SO}_{4}$. However, feed intake was reduced at the $2,814 \mathrm{ppm} \mathrm{SO}_{4}$ level and growth rate was reduced at the $1,462 \mathrm{ppm} \mathrm{SO}_{4}$ level or higher. Concentrations of $3,493 \mathrm{ppm} \mathrm{SO}_{4}$ reduced feed intake and resulted in weight loss in cattle (Weeth and Hunter 1971). Other studies reported tolerances of cattle to $\mathrm{SO}_{4}$ concentrations up to $4,732 \mathrm{ppm}$ but water intake was depressed by $20 \%$ at concentrations of 6,760 ppm (Embry et al. 1959).

Nutrient loading in dugouts also promotes the growth of algae that affect water quality by causing eutrophication and, more seriously, poisoning when toxic blue-green algae are present. There are several genera of algae that belong to the group commonly referred to as toxic bluegreen algae. They include Anacystic, Anabaena, Aphanizomenon, Nodularia, and Oscillatoria and are associated with 2 types of toxins, hepatotoxins and neurotoxins (Beasley et al. 1989). While the toxicity of blue-green algae has been clearly identified, the effect of subclinical doses of these toxins on animal performance and water palatability are still not well defined.

Perhaps the most predictable factor reducing palatability of water is fecal contamination, yet very few studies have examined the effects on water consumption. Holechek (1980) reported a decrease in water consumption and weight gain of cattle drinking from a water source contaminated with feces and urine. Conversely, Crawford et al. (1996) reported no difference in weight gain of cattle drinking water from a pond to which they had direct access. In a pilot study, we found that cattle drinking from a dugout gained $23 \%$ less weight than those drinking clean water delivered to a trough. As a result of this evidence, a study was conducted to examine the effects of water source on cattle production and activity behavior in field experiments, to determine the impact of selected chemical and biological constituents on these observed responses, and to test the effect of fecal contamination on water consumption in penned trials.

\section{Materials and Methods}

The effect of water source was tested during the summer in southern Alberta; 2 sites were tested near Stavely $\left(50^{\circ} 12^{\prime}\right.$, $\left.113^{\circ} 57^{\prime}\right)$ in the fescue prairie and 1 at Onefour in the mixed prairie $\left(49^{\circ} 04^{\prime}\right.$, $\left.110^{\circ} 27^{\prime}\right)$. One additional site was located in south central British Columbia near Kamloops $\left(50^{\circ} 33^{\prime}, 120^{\circ} 08^{\prime}\right)$. The Kamloops grasslands were similar to the Stavely site having a dominance of rough fescue (Festuca campestris Rydb.). The mixed prairie site was representative of the Stipa-Bouteloua faciation of the mixed prairie (Coupland 1961).

\section{Cattle response to water source (field trial)}

Two experiments were conducted to determine the effects of water source on performance of Hereford cattle: One examined the effects on yearling cattle (Yearling Experiment) while the second examined the effects on cow-calf pairs (Cow-Calf Experiment). The Yearling Experiment was conducted at 3 sites, repeated in 3 to 5 years (random variable), and had 3 water-source treatments. The sites (with number of trial-years) were at Kamloops (5), Stavely (3), and Onefour (5). The treatments were (1) clean water supplied either from a well, a spring, or a river into a trough, (2) water pumped from a pond or dugout (hereafter referred to as a pond) into a trough (Pond trough $_{\text {) and the }}$ pond fenced to prevent access, or (3) direct access by cattle to the pond $\left(\right.$ Pond $\left._{\text {direct }}\right)$. Clean water was transported by truck and stored in a 5,500 liter storage tank that was insulated to minimize light and moderate water temperatures. Flow of water from the tank was controlled by a float valve in the trough. Water for the Pond $_{\text {trough }}$ was delivered with an electric pump activated by a depth sensor in the trough. The trials were facilitated with 3 paddocks of equal area, radiating from a pond, and randomly assigned to a treatment in each trial-year. The same ponds and paddocks were used repeatedly over the study period.

The Cow-Calf Experiment was conducted at a second pond at Stavely over 6 years. The arrangement of paddocks and treatments were the same as that for the Yearling Experiment. The treatments were randomized among paddocks each year.

\section{Cattle performance \\ Yearling Experiment}

Each paddock was stocked with 10, 16mo old yearling cattle over a 2-mo period between July and September of each year. Animal size among treatments was harmonized by ranking the 30 test animals by weight and randomly allocating them in groups of 3 among the treatments. Open heifers were used in all years at Onefour and in 2 years at Kamloops and 1 year at Stavely. Steers were used in 3 years at Kamloops and 2 years at Stavely. The trials at Stavely were terminated early, and the data not used in the analyses, when the animals escaped their paddocks in 1996 and insufficient water was available to complete the trial in 1999 . The average stocking rates were $2.08,0.69$, and 0.86 animal-unit-month (AUM) $\mathrm{ha}^{-1}$ on sites at Stavely, Onefour, and Kamloops, respectively. The stocking rates were matched with the pasture condition to ensure that forage did not limit cattle production.

\section{Cow-Calf Experiment}

Each paddock was stocked with 10 cowcalf pairs for a 2-mo period except in 1994 when 6 pairs were used. The protocol for allocating cow-calf pairs among treatments was the same as for yearlings except that backfat thickness was used to rank the animals. The average stocking rate, since 1994, was $2.96 \mathrm{AUM} \mathrm{ha}^{-1}$. The proportion of male to female calves was maintained constant among treatments to account for differences in growth and demands on the cow. The cows were obtained from the same herd each year and bred for calving in March.

Animal weights were determined at the beginning and end of each trial. At the time of weighing, backfat thickness was measured, for cows only, at the spinal process above the $11^{\text {th }}$ rib on the left side of the animal about $15 \mathrm{~cm}$ from the midlines of the vertebrae using a portable 
Krautkramer USK 7 ultrasound machine (Krautkramer Branson, Hürth, Germany). Changes in weight and backfat thickness were assessed over the duration of the trial.

\section{Cattle activity}

Estimates of cattle activity and drinking times were made with direct observations on the herd and individual animals, respectively, at Stavely (2 sites) and Onefour (1 site), and on individuals at all 4 sites over 2 to 6 years. Thus, both cows with calves and yearlings were observed. The observers positioned themselves at a vantage point from where all 3 paddocks could be seen and drinking times of individual animals could be measured. Individual animals were identified by unique physical or color markings. Thirty, half-hour observations were made simultaneously on herd activity at each water source from dawn to dusk, over 3 to 5 days during 3 years. Herd activity was recorded as grazing intensely, grazing lightly, loafing, resting, or drinking. Grazing lightly was defined as feeding while walking; loafing included socializing and standing while resting involved lying down. Drinking activity was defined as the time committed to obtaining water and includes ingestion and positioning for the purpose of ingesting water. This differs from the observation on individual animals where drinking was defined as actively ingesting water.

Observations on individual animals were focused on estimating time spent ingesting water as an index of volume consumed. Two animals were selected in each treatment for observation, from dawn to dusk over the duration of the sampling period. Drinking times were measured with a stopwatch.

\section{Chemical and biological quality of water}

Water samples $(250 \mathrm{ml})$ were collected at the time cattle were weighed from each source by dipping a sterile bottle into water at a depth and place from where cattle would normally drink. The samples were immediately cooled and delivered to a commercial laboratory for analysis of elemental and microbiological constituents. Water quality (chemistry and bacteria) in Alberta was tested by the Trace Elements/Environmental Toxicology Laboratory at the University of Alberta, Edmonton, Alberta. In British Columbia, the analyses were performed by the Pacific Environmental Science Centre of Environment Canada, Vancouver, British Columbia.

Only pond water was sampled (Pond $_{\text {direct }}$, Pond $_{\text {trough }}$ ) for algae in 1998 and 1999 at each site and in 1997 at both Stavely sites. The clean water was not sampled since algae biomass was negligible. At Stavely and Onefour, samples were taken every 2 weeks beginning at the start of each trial while at Kamloops water was sampled 2 weeks after the start and 2 weeks before the end of the trial.

Water was sampled for algae with a plankton net having a diameter of $11.2 \mathrm{~cm}$. The net was drawn at a fixed distance through the water to a depth of $30 \mathrm{~cm}$. In the pond, three, $1.5-\mathrm{m}$ long samples were taken at different locations and composited. A single $60-\mathrm{cm}$ long sample was taken in the trough. Total volume sampled was 45 liters from the pond and 6 liters from the trough. After sampling, the bottles were immediately placed in a cooler in preparation for analysis. Algae were examined and identified to genus according to Clesceri et al. (1989) and reported as cell numbers liter $^{-1}$. The algae species were classified according to toxic bluegreen of the genera Anabaena, Anacystis, Aphanizomenon, Arthrospira, and Oscillatoria and others (Ceratium, Diatoma, Dinobryon, Euglena, Fragilaria, Gomphosphaeria, Spirogyra, Synedra, Tabellaria, and Volvox) that were recognized for reducing palatability for humans through odor or taste (Ingram and Prescott 1954, Palmer 1959).

\section{Statistical analyses}

Weight changes in the Yearling Experiment were analyzed as a factorial that included 3 water treatments, 3 sites, years nested in site, and their interactions. For the Cow-Calf Experiment, changes in weight of both cows and calves, and backfat thickness of cows were analyzed as a factorial with sex of calf, 3 water treatments, replication over years, and their interactions. All analyses were evaluated using mixed effects ANOVA (SAS 1999) with year being a random variable. Treatment means were compared using single degree of freedom contrasts.

Observations on herd activity were analyzed in a factorial arrangement that included 3 water treatments, 3 sites, and years $(n=2$ to 6$)$ nested in site. All analyses were evaluated using a mixed effects ANOVA (SAS 1999) with year being a random variable. Treatment means were compared using single degree of freedom contrasts. Drinking times were estimated over 4, 6, 3, and 2 years at Stavely (Cow Experiment), Stavely (Yearling Experiment), Onefour, and Kamloops, respectively and analyzed with the same model used for activity.

\section{Role of pathogens and parasites on cattle performance}

The potential role of pathogens and parasites in affecting cattle performance was tested by comparing infection rates among water source treatments and between infected and non-infected animals. Rectal faecal samples were taken at the time of weighing both in 1996 and 1997 at 2 Stavely sites (Yearling and Cow Experiments) and at Onefour. The samples were kept refrigerated until analyzed for the presence of Giardia spp. cysts, Cryptosporidium spp. oocysts, and nematode eggs.

\section{Analysis of Giardia and Cryptosporidium spp.}

Fecal suspensions were squeezed and filtered through 4 layers of NuGauze (Johnson and Johnson, Montreal, Canada) to yield $7 \mathrm{ml}$ of filtrate. The filtrate was layered over $5 \mathrm{ml}$ of $1 \mathrm{M}$ sucrose (specific gravity 1.13) and centrifuged at $800 \mathrm{x} \mathrm{g}$ for $5 \mathrm{~min}$ to concentrate the cysts at the sucrose/water interface. The interface and upper layer of liquid were transferred by pipette to a clean tube and recentrifuged ( $800 \mathrm{x} \mathrm{g}$ for $5 \mathrm{~min})$. The supernatant was decanted and the pellet was suspended in sodium phosphate buffered saline to a volume of $1 \mathrm{ml}$.

Two, 0.015-ml samples of the concentrate were spotted on microscope slides and allowed to air dry on a slide warmer for a minimum of $30 \mathrm{~min}$. Once dry, the slide was fixed with acetone, dried, and mixed with $20 \mu \mathrm{l}$ of either Giardia or Cryptosporidium fluorescein isothiocyanate labeled monoclonal antibody solution (Giardi-a-glo, Crypt-o-glo, Waterborne, New Orleans, La). The sample was then incubated in a humidity chamber at $37^{\circ} \mathrm{C}$ for $30 \mathrm{~min}$. After incubation, slides were rinsed with phosphate buffered saline and the slide was left to air dry. Once dry, slides were mounted with glycerol (Aquapolymount, Polysciences, Warrington, Penn.) and a cover slip and examined using an epifluorescent microscope at 200 $x$ and $400 x$ magnification. The number of cysts (Giardia) and oocysts (Cryptosporidium) over the spotted area were counted and subsequently the number of cysts or oocysts per gram of feces was calculated. Oocysts of $C$. muris were differentiated 
from those of $C$. parvum based upon their spherical size and shape 6.6-7.9 Fm x 5.3$6.5 \mathrm{Fm}$, ovoid for $C$. muris; 4.5-5.4 x 4.2$5.0 \mathrm{Fm}$, spherical for C. parvum). Oocysts and cysts from all samples were identified and enumerated by the same individual and previously established positive and negative control fecal samples were analyzed with each sample lot. The immunologial reagents have been shown to be specific for Giardia spp. cysts and Cryptosporidium oocysts (Xiao et al. 1994, Olson et al. 1997b) with a sensitivity of 67 cysts/oocysts gram $^{-1}$ of feces.

\section{Analysis of Nematodes}

Ova of parasitic nematodes and cestodes were enumerated using a modification of the technique described by Cox and Todd (1962). Five gram samples of feces were diluted with $22 \mathrm{ml}$ of $2.5 \%$ potassium dichromate solution, filtered through 2 layers of cheesecloth, and centrifuged for $10 \mathrm{~min}$ at $5,000 \mathrm{x} \mathrm{g}$, The pellet was resuspended in a saturated sugar solution and centrifuged at $5,000 \times \mathrm{g}$ for $10 \mathrm{~min}$. The eggs on two, $22 \times 22 \mathrm{~mm}$ cover-slips were identified and enumerated. Eggs of Nemetodirus spp., Trichuris spp. and Monenzia were identified. Eggs of other trichostrongyle genera could not be differentiated and were identified as "trichostrongyle."

\section{Statistical analysis}

Analyses were made to determine (1) whether the water sources had an effect on infection rates of the cattle and (2) whether weight gains were related to infection. Since counts of organisms or eggs does not reliably estimate their degree of impact on the animal, the comparison in the first analysis was based on the number of animals infected by the specific organism and, in the second analysis, on the weight gain of animals infected versus non-infected by the specific organism. In each case, infection was determined by the presence or absence of the organism, identified by genus, in the fecal sample. Analyses were made for Giardia spp., Cryptosporidium spp., "trichostrongyle" spp., and Nematodirus spp. Presence or absence of the remaining organisms were not sufficiently balanced to permit a meaningful comparison.

The effect of water source on infection was based on the final fecal sample taken at the conclusion of the trials and analyzed as a factorial using a mixed effects ANOVA (SAS 1999) model with year ( $\mathrm{n}$ $=2$ ) the random variable. The fixed factors were 3 sites and 3 water treatments and their interaction. The effects of infection on weight gain were analyzed by pooling animals across water source treatments and analyzing their weight gain as a factorial using a mixed effect ANOVA (SAS 1999) model with year $(n=2)$ being the random variable and fixed factors of 2 infection treatments, 3 sites, and their interaction. Replication was achieved by individual animals.

\section{Effect of fecal contamination on water consumption (penned trials)}

Two experiments were conducted to determine cattle response to manure contamination in penned trials. In each experiment, manure was collected fresh at the beginning of each trial from a nearby pasture and refrigerated in an air-tight container to be used as required. Water was offered in 140-liter water troughs, constructed from tires, and having the water intake at the bottom and designed to stir the water and mix the sediments as the animal was drinking. This would simulate the effect of an animal walking into a pond and disturbing the muck. The flow of water into the trough was controlled with a float valve and was metered to determine daily consumption. Manure was added at the beginning of each trial and then daily in amounts proportional to water consumption.

Sixteen-month old yearling steers were used in each experiment. Before every trial, the animals were brought into a holding area and fed cubed alfalfa hay and offered clean water from a well. The same hay and water was offered to the animals during the trials with the only exception being the rates of manure contamination.

\section{Effect of contaminants on water selection}

The effect of manure contamination on water selection was tested with choices of 3 concentrations $(0,0.05$, and $0.25 \mathrm{mg}$ manure gram ${ }^{-1}$ water) and 4 replications. Three troughs spaced about 1-m apart were arranged in a row at one end of the pen and treatments were allocated randomly for each replication. Eight steers were randomly assigned to 4 groups of 2 animals each and allocated among replicates. The replications were run consecutively over 7 days each.

\section{Effect of contaminants on water and feed intake}

The effect of manure contamination on water and feed intake was examined in 2 trials, each designed in a $4 \times 4$ Latin square with 4 treatments, 4 pens, and 4 times. Each time consisted of observations over 10 days that were repeated consecutively after changing the assigned treatment in each pen according to design. For the analyses, the observations were divided into 2, 5-day periods with the first representing a conditioning period. Eight steers were randomly allocated into 4 groups of 2 animals each and assigned to a pen for the duration of the trial. The 4 treatments in Trial 1 were concentrations of manure at $0,0.05,0.15$, and $0.45 \mathrm{mg}$. gram $^{-1}$ water and in Trial 2 the concentrations were $0,2.5,5.0$, and $7.5 \mathrm{mg} \mathrm{gram}^{-1}$ water. Different animals were used between trials and the hay was weighed in and out each day to determine feed intake.

\section{Statistical analysis}

The water selection study was analyzed as a split plot design with an unstructured error matrix using a mixed effects model (SAS 1999). This allowed the analyses of day since trial intiation, and its interaction with treatment, as a repeated measure and permitted a more detailed examination of the daily adjustment by the animals to the treatments. The main effects were 3 water contamination treatments and 7 days of exposure. The water contamination treatment was tested by its interaction with replication. Day since trial initiation and its interaction with treatment was tested by the residual. As a result of a significant $(P$ $=0.004$ ) interaction of water treatment and day, selection in each day was analyzed separately and the means compared with single degree of freedom contrasts.

The effects of contaminants on feed intake by 2 animals were analyzed for both periods. Average water and feed intakes for each period were determined and analyzed using ANOVA (SAS 1999) for each trial separately. Treatment means were compared using single degree of freedom contrasts. The relationship between water and feed intake was evaluated with a simple linear regression across treatments and periods for each trial (SAS 1999).

\section{Results}

\section{Cattle response to water source (field trial) Chemical and biological quality of water}

Well water had more $\mathrm{Na}, \mathrm{CaCO}_{3}$, and $\mathrm{SO}_{4}$ than water from ponds at Stavely and Onefour (Table 1). The concentration of salt, as measured by conductivity $\left(\mathrm{Fs} \mathrm{cm}^{-1}\right)$, from well water was greatest at Onefour. Pond water at Kamloops had concentra- 
Table 1. Chemical characteristics and coliform counts $(\bar{x} \pm 1$ SE) in water offered to cattle at 4 sites.

\begin{tabular}{|c|c|c|c|c|c|c|c|c|c|c|c|c|c|}
\hline \multicolumn{2}{|l|}{ Site } & Treatment & $\mathrm{pH}$ & Conductivity & $\mathrm{Na}$ & $\mathrm{K}$ & $\mathrm{Ca}$ & $\mathrm{CaCO}_{3}$ & $\mathrm{NO}_{3}+\mathrm{NC}$ & $\mathrm{O}_{2}$ Sulphate & $\begin{array}{l}\text { Total } \\
\text { TDS }^{1}\end{array}$ & $\begin{array}{c}\text { Faecal } \\
\text { Coliform } \\
\end{array}$ & Coliform \\
\hline & & & & $\left(\mu \mathrm{s} \cdot \mathrm{cm}^{-1}\right)$ & $\cdot\left(\mathrm{mg}^{-1}\right)$ & $(\mathrm{mg})$ & $\begin{array}{l}(\mathrm{mg} \\
\left.\cdot \text { liter }^{-1}\right)\end{array}$ & $\begin{array}{l}(\mathrm{mg} \\
\left.\cdot \text { liter }^{-1}\right)\end{array}$ & $\begin{array}{l}(\mathrm{mg} \\
\left.\cdot \text { liter }^{-1}\right)\end{array}$ & $\begin{array}{l}(\mathrm{mg} \\
\left.\cdot \text { liter }^{-1}\right)\end{array}$ & $\left(\begin{array}{l}\text { (mg } \\
\left.\text { liter }^{-1}\right)\end{array}\right.$ & $\begin{array}{l}(\text { no. } \\
\left.100 \mathrm{ml}^{-1}\right)\end{array}$ & $\begin{array}{l}\text { (no: } \\
100 \mathrm{ml}^{-1} \text { ) }\end{array}$ \\
\hline \multicolumn{3}{|c|}{ Canadian Water Quality Guidelines (1999) } & & & & & 1000 & & 100 & 1000 & 3000 & & 1000 \\
\hline \multirow{4}{*}{$\begin{array}{l}\text { Stavely - c } \\
(1995-98)\end{array}$} & $\mathrm{n}=11, \mathrm{yr}=5$ & Clean $^{3}$ & 8.50 & 1032 & 227 & 2.35 & 24 & 365 & 0.20 & 181 & 675 & 177 & 108 \\
\hline & & & 0.04 & 44 & 19 & 0.17 & 3 & 5 & 0.04 & 16 & 32 & 92 & 83 \\
\hline & $\mathrm{n}=11, \mathrm{yr}=5$ & Pond & 7.87 & 347 & 4 & 8.71 & 42 & 169 & 0.06 & 3 & 177 & 279 & 233 \\
\hline & & & 0.06 & 15 & 0.3 & 0.76 & 3 & 7 & 0.00 & 1 & 7 & 124 & 39 \\
\hline \multirow{4}{*}{$\begin{array}{l}\text { Stavely - } y^{4} \\
(1995-99)\end{array}$} & $\mathrm{n}=7, \mathrm{yr}=4$ & Clean $^{3}$ & 8.51 & 1027 & 228 & 2.26 & 22 & 362 & 0.13 & 183 & 673 & 8 & 6 \\
\hline & & & 0.05 & 56 & 19 & 0.13 & 2 & 12 & 0.02 & 14 & 36 & 4 & 2 \\
\hline & $\mathrm{n}=8, \mathrm{yr}=4$ & Pond & 8.41 & 356 & 6 & 7.33 & 32 & 177 & 0.05 & 10 & 185 & 257 & 149 \\
\hline & & & 0.11 & 28 & 2 & 0.84 & 4 & 19 & 0.00 & 2 & 19 & 166 & 10 \\
\hline \multirow[t]{6}{*}{ Onefour - $y$} & $\mathrm{n}=5, \mathrm{yr}=4$ & Clean $^{3}$ & 8.76 & 3296 & 826 & 4.84 & 13 & 684 & 0.06 & 1046 & 2324 & 15 & 4 \\
\hline & $(1994-99)$ & $(1994-97)$ & 0.05 & 673 & 176 & 0.34 & 1 & 42 & 0.00 & 312 & 379 & 6 & 7 \\
\hline & $\mathrm{n}=2, \mathrm{yr}=2$ & Clean $^{5}$ & 8.17 & 225 & 8 & 1.0 & 21 & 92 & 0.05 & 14 & 110 & 4 & 4 \\
\hline & $(1998-99)$ & & - & - & - & - & - & - & - & - & - & - & - \\
\hline & $\mathrm{n}=7, \mathrm{yr}=6$ & Pond & 8.83 & 250 & 24 & 8.37 & 16 & 115 & 0.06 & & 31 & 93 & 58 \\
\hline & & & 0.33 & 13 & 5 & 0.84 & 1 & 7 & 0.00 & 1 & 11 & 32 & 25 \\
\hline \multirow{6}{*}{$\begin{array}{l}\text { Kamloops - y } \\
(1995,98-99)\end{array}$} & $\mathrm{n}=1, \mathrm{yr}=1$ & Clean $^{6}$ & 7.78 & 2408 & 132 & 27.00 & 127 & 875 & 0.05 & 765 & 1783 & 24 & 24 \\
\hline & 1995 & & - & - & - & - & - & - & - & - & - & - & - \\
\hline & $\mathrm{n}=4, \mathrm{yr}=2$ & Clean $^{5}$ & 8.46 & 95 & 2 & 1.37 & 13 & 36 & 0.01 & 6 & - & 35 & 16 \\
\hline & $1998-99$ & & 0.24 & 2 & 0 & 0.11 & 0 & 1 & 0.00 & 0 & 22 & 9 & \\
\hline & $\mathrm{n}=5, \mathrm{yr}=3$ & Pond & 9.00 & 9596 & 1276 & 142.50 & 70 & 836 & 0.00 & 5900 & - & 531 & 182 \\
\hline & & & 0.04 & 3002 & 431 & 60.62 & 10 & 100 & 0.00 & 2292 & & 63 & 62 \\
\hline
\end{tabular}

Total dissolved solids.

${ }^{2}$ Denotes trial with cow-calf pairs.

${ }^{3}$ Clean water taken from a well.

${ }_{5}^{4}$ Denotes trial with yearling cattle.

${ }^{5}$ Clean water taken from a river.

${ }^{6}$ Clean water taken from a spring.

tions of $\mathrm{SO}_{4}$ that varied from 7,900 to $18,000 \mathrm{mg} \mathrm{liter}^{-1}$ from July to September, respectively, in 1998 and from 1,440 to 3,810 $\mathrm{mg} \mathrm{liter}^{-1}$ from May to September, respectively, in 1999. A single sample measured in August 1995 had 2,600 mg liter ${ }^{-1} \mathrm{SO}_{4}$. Water sampled from all sites had $\mathrm{NO}_{2}+\mathrm{NO}_{3}$ levels that were well below toxic levels for cattle (Table 1 ). Clean water from all sources had fewer coliforms than water from ponds.

Toxic blue-green algae were present at all sites at concentrations up to $7.5 \times 10^{6}$ cells liter $^{-1}$ (Table 2). Other algae genera capable of producing odours or unpleasant taste for humans were also present in mostly lower concentrations than those detected for the toxic algae.

Table 2. Average algae densities $\left(\left(\text { cells } \cdot \text { liter }^{-1}\right)^{-1000}\right)$ at biweekly intervals over the trial periods at Stavely and Onefour and near the beginning and end of trials at Kamloops in pond water offered by direct access or in a trough.

\begin{tabular}{|c|c|c|c|c|c|c|c|c|c|c|c|c|c|c|c|c|c|c|}
\hline \multirow[b]{4}{*}{ Algae Genera } & \multicolumn{6}{|c|}{ Cow-calf } & \multicolumn{12}{|c|}{ Yearling } \\
\hline & \multicolumn{6}{|c|}{ Stavely } & \multicolumn{4}{|c|}{ Stavely } & \multicolumn{4}{|c|}{ Onefour } & \multicolumn{4}{|c|}{ Kamloops } \\
\hline & \multicolumn{2}{|c|}{1997} & \multicolumn{2}{|c|}{1998} & \multicolumn{2}{|c|}{1999} & \multicolumn{2}{|c|}{1997} & \multicolumn{2}{|c|}{1998} & \multicolumn{2}{|c|}{1998} & \multicolumn{2}{|c|}{1999} & \multicolumn{2}{|c|}{1998} & \multicolumn{2}{|c|}{1999} \\
\hline & \multicolumn{2}{|c|}{$\overline{\text { Direct Trough }}$} & \multicolumn{2}{|c|}{ Direct Trough } & \multicolumn{2}{|c|}{ Direct Trough } & \multirow{2}{*}{ Direct } & Trough & \multicolumn{2}{|c|}{ Direct Trough } & \multicolumn{2}{|c|}{ Direct Trough } & \multirow{2}{*}{\multicolumn{2}{|c|}{ Direct Trough }} & \multicolumn{2}{|c|}{ Direct Trough } & \multicolumn{2}{|c|}{ Direct Trough } \\
\hline $\mathrm{n}$ & $--5 \ldots$ & -4 & -4 & $-4_{--}$ & 3 & $-{ }_{-3}$ & & --4 & $-4_{-}$ & --3 & $-{ }_{-4}$ & --3 & & & -2 & $-2 \ldots$ & -2 & $-2--$ \\
\hline Toxic blue-green & & & & & & & & & & & & & & & & & & \\
\hline Anabaena & 13 & 8 & 12 & 10 & 4 & & 17 & 12 & 134 & 24 & 3 & 2 & 22 & 35 & 1 & & 255 & 8 \\
\hline Anacystis & & 4 & 10 & 2 & 101 & 41 & 3 & 8 & 1 & 8 & $\mathrm{~T}^{2}$ & 15 & 143 & 77 & & & 142 & \\
\hline Aphanizomenon & $\mathrm{T}$ & $\mathrm{T}$ & $\mathrm{T}$ & 1 & & & 8 & 2 & $\mathrm{~T}$ & & $\mathrm{~T}$ & 2 & $\mathrm{~T}$ & & & & & \\
\hline Arthrospira & 17 & 10 & & & & & 2 & & & & 2 & & & & & & & \\
\hline Oscillatoria & 66 & 36 & 192 & 18 & 19 & 12 & 28 & 13 & 47 & 4 & 19 & 35 & 91 & 11 & 6 & 1 & 10 & \\
\hline Total & 109 & 193 & 258 & 31 & 12 & 61 & 7582 & 1791 & 230 & 35 & 374 & 1858 & 315 & 123 & 7 & 1 & 406 & 8 \\
\hline \multicolumn{19}{|l|}{ Other $^{1}$} \\
\hline Ceratium & $\mathrm{T}$ & 1 & 3 & 1 & 33 & 37 & 12 & 12 & $\mathrm{~T}$ & $\mathrm{~T}$ & $\mathrm{~T}$ & $\mathrm{~T}$ & 3 & 2 & 1 & $\mathrm{~T}$ & & \\
\hline Diatoma & 2 & 2 & 35 & 16 & 1 & $\mathrm{~T}$ & 2 & 1 & 22 & 119 & 10 & 11 & $\mathrm{~T}$ & $\mathrm{~T}$ & 66 & 1141 & 6 & 2 \\
\hline Dinobryon & & & 1 & & & & & & 1 & 1 & & & & & $\mathrm{~T}$ & & & \\
\hline Euglena & $\mathrm{T}$ & $\mathrm{T}$ & $\mathrm{T}$ & $\mathrm{T}$ & & & 1 & $\mathrm{~T}$ & $\mathrm{~T}$ & & $\mathrm{~T}$ & & & & $\mathrm{~T}$ & 1 & & \\
\hline Fragilaria & 1 & 11 & 3 & & $\mathrm{~T}$ & 1 & 66 & 7 & 37 & 12 & $\mathrm{~T}$ & 1 & $\mathrm{~T}$ & & 1 & 1 & 9 & 1 \\
\hline Gomphosphaeria & $\mathrm{T}$ & & 34 & 2 & 2 & 2 & 3 & & 2 & & 1 & & $\mathrm{~T}$ & $\mathrm{~T}$ & & & & \\
\hline Spirogyra & 372 & 9 & 6 & 10 & 4 & & 4 & 3 & 18 & 201 & 1 & 1 & 18 & 7 & 7 & & 21 & 11 \\
\hline Synedra & & & & & $\mathrm{T}$ & & & & & & & & & & & & $\mathrm{T}$ & \\
\hline Tabellaria & & & & & & & & & & & & & $\mathrm{T}$ & & & & 2 & \\
\hline Volvox & $\mathrm{T}$ & $\mathrm{T}$ & & & & & 384 & $\mathrm{~T}$ & & & & & & & & & & \\
\hline
\end{tabular}

${ }_{2}^{1}$ All genera represent algae that can affect palatability to humans through odour or taste.

${ }^{2}$ Trace - less than 1 (cells $\cdot$ liter $\left.^{-1}\right)^{-1000}$. 
Table 3. Effect of water supply on weight and backfat thickness of $\operatorname{cows}^{1}$, and weight gains of calves $^{1}$ and yearlings ${ }^{2}$ over 3 to 6 years.

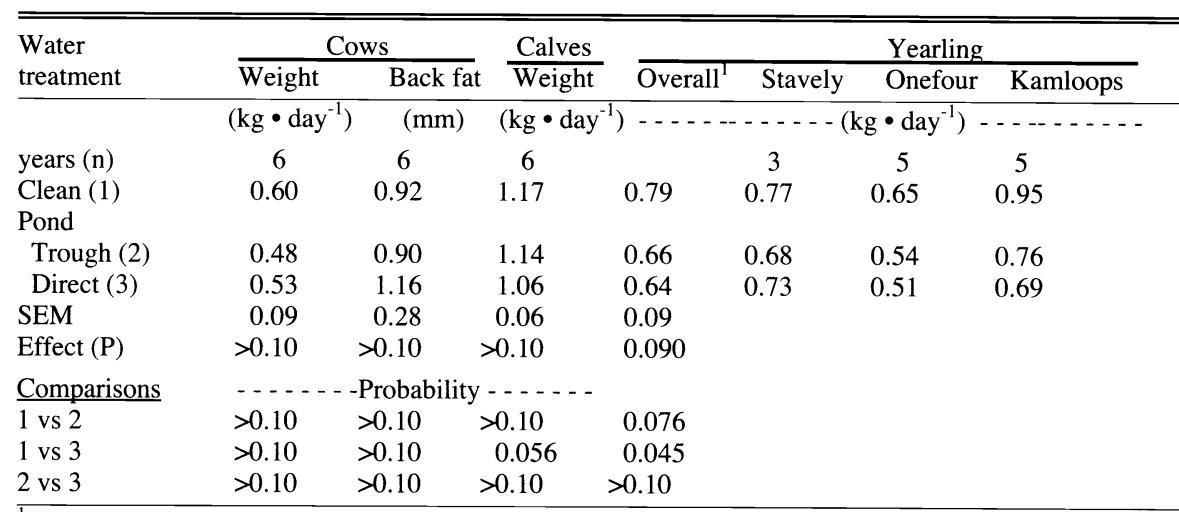

${ }^{1}$ The interaction of calf sex, or its interaction with treatment, was not significant $(P>0.10)$ for weight or backfat thickness in cows; weight gains in calves was affected $(P=0.004)$ by sex; the interaction of sex $x$ treatment was not significant $(\mathrm{P}>0.10)$

${ }^{2}$ The site $\mathrm{x}$ treatment interaction was not significant $(\mathrm{P}>0.10)$

\section{Cattle performance}

Clean water produced 23 and $20 \%$ greater $(P<0.10)$ weight gains, among yearling cattle, than pond direct $_{\text {or }}$ pond $_{\text {trough }}$, respectively (Table 3 ). The effect was similar $(P>0.10)$ across sites but less evident at Stavely (Table 3 ). Weight gains in relation to water source was not consistent among years. The greatest deviation from the average trend was a $3.7 \%$ greater gain on pond $d_{\text {direct }}$ than from clean water at Kamloops in 1995 (Data not shown).

The effect of water source treatment on weight gains of cows with calves was not significant $(P>0.10)$ although average weight gains were 13 and $25 \%$ more for cows drinking clean water than from pond direct $_{\text {or pond }}$ trough, respectively (Table 3). Backfat thickness also was not responsive $(P>0.10)$ to water treatments
(Table 3) and calf sex had no effect $(P>$ 0.10 ) on weight or backfat thickness (Data not shown). Calves on clean water gained more weight than calves having direct access to pond water $(P=0.056)$ while pond water pumped to a trough produced intermediary results $(P>0.10$, Table 3$)$. Male calves gained more $(P=0.004)$ weight than female calves (1.18 vs $1.07 \mathrm{~kg}$ - day ${ }^{-1}$; data not shown).

\section{Cattle activity}

Cattle offered clean water spent more time grazing $(P=0.002)$ and less time resting $(P<0.001)$ and loafing $(P=0.029)$ than cattle drinking directly from the pond (Table 4). Drinking activity and drinking times were similar $(P>0.10)$ among treatments. Activity behaviors were similar $(P$ $>0.10$ ) among treatment at each site except for resting at Stavely where clean $=$ pond $_{\text {trough }}<$ pond $_{\text {direct }}$ and at Onefour where clean $<$ pond $_{\text {trough }}=$ pond $_{\text {direct }}$.

\section{Role of pathogens and parasites in cattle performance}

Infections by Giardia, Cryptosporidium, Trichostrongylus, or Nematodirus spp. were similar $(P>0.10)$ among water treatments and sites. Animal weight gains were not affected $(P>0.10)$ by infection as indicated by the presence of the organisms tested in the feces (Table 5).

\section{Effect of fecal contamination on water consumption (penned trials)}

Cattle tended to avoid water that was contaminated by $0.05 \mathrm{mg}$ fresh manure $\cdot \mathrm{g}$ ${ }^{1}$ water, preferring to consume water without manure when given a choice (Table 6). This effect was consistent in each day of the trial except on the first day when they drank similar $(P>0.10)$ amounts of clean water and water contaminated with 0.05 $\mathrm{mg}$ manure gram $^{-1}$ water. However, when a single choice was offered, water consumption was depressed only at manure concentrations above $2.5 \mathrm{mg}$ gram $^{-1}$ water while feed consumption was depressed at concentrations greater than 5 $\mathrm{mg} \bullet \mathrm{gram}^{-1}$ water (Table 7). The relationship between feed intake and water consumption was expressed by the equations: Feed $_{\mathrm{kg}}=6.2 \mathrm{~kg}+0.16 \mathrm{~kg} \cdot$ liter $^{-1}$ for Trial 1 $\left(r^{2}=0.78, P<0.001\right)$; and Feed $_{\mathrm{kg}}=13.6 \mathrm{~kg}$ $+0.04 \mathrm{~kg} \cdot \operatorname{liter}^{-1}$ for Trial $2\left(\mathrm{r}^{2}=0.20, P<\right.$ $0.001)$. The response represents a ratio of about 6 and 25 liter water $\bullet \mathrm{kg}^{-1}$ dry matter consumed in Trials 1 and 2, respectively.

\section{Discussion}

Table 4. Budget of cattle activities and drinking times in relation to water source at several sites over 2 to 6 years at each location ${ }^{1}$.

\begin{tabular}{|c|c|c|c|c|c|}
\hline Water treatment & Grazing & Resting & Loafing & $\begin{array}{l}\text { Drinking } \\
\text { activity }^{2}\end{array}$ & $\begin{array}{c}\text { Drinking } \\
\text { time }^{3}\end{array}$ \\
\hline & \multicolumn{3}{|c|}{$\ldots$} & \multicolumn{2}{|c|}{$\cdots\left(\sec \bullet\right.$ day $\left.^{-1}\right) \cdots$} \\
\hline Clean & 18.1 & 8.3 & 1.0 & 1.4 & 77 \\
\hline \multicolumn{6}{|l|}{ Pond } \\
\hline Trough & 16.5 & 9.5 & 1.6 & 1.2 & 80 \\
\hline Direct & 15.7 & 9.8 & 2.3 & 1.0 & 85 \\
\hline SEM & 0.7 & 0.2 & 0.2 & 0.1 & 3 \\
\hline \multicolumn{6}{|l|}{ Source - } \\
\hline Site (1) & $>0.10$ & $>0.10$ & $>0.10$ & $>0.10$ & $<0.001$ \\
\hline Treatment (2) & 0.002 & $<0.001$ & 0.029 & $>0.10$ & 0.316 \\
\hline $1 \times 2$ & $>0.10$ & 0.048 & $>0.10$ & $>0.10$ & 0.985 \\
\hline \multicolumn{6}{|c|}{ Treatment Comparisons } \\
\hline 1 vs 2 & 0.007 & $<0.001$ & $>0.10$ & $>0.10$ & $>0.10$ \\
\hline 1 vs 3 & 0.001 & $<0.001$ & 0.010 & $>0.10$ & $>0.10$ \\
\hline 2 vs 3 & 0.091 & 0.089 & $>0.10$ & $>0.10$ & $>0.10$ \\
\hline
\end{tabular}

Activity budgets were estimated at 2 Stavely sites (cow-calf and yearling) and at Onefour over 3, 2, and 2 years respectively; drinking times were estimated at 2 Stavely sites (cow-calf and yearling), at Onefour and at Kamloops over 6, 4, 3 and 2 years, respectively.

${ }^{2}$ Time that is committed to obtaining water; includes drinking and positioning for the purpose of drinking.

${ }^{3}$ Time that is spent ingesting water; the mouth is in contact with the water surface.

\section{Effect of water source}

The effects of pond water on weight gains among yearling cattle were similar among a diverse range of sites but considerable differences existed among years for both cows and yearlings (Table 3 ). Because the response was measured relative to clean water, the yearly treatment response is a function of acceptance or avoidance of both sources. As such, errors of interpretation could be introduced from the lack of an unsuitable control. Clean water obtained from wells at Stavely and Onefour had higher concentrations of salt than water from ponds although they were within the acceptable limits (Table 1). However, the criteria defining water quality that explained cattle performance were not likely estimated by the chemical or 
Table 5. Weight gains of cows (with calves) and yearling cattle over a 2-month period in relation to infection (No - absent; yes - present) by Giardia spp., Cryptosporidium spp., and gastrointestinal nematodes ('trichostrongyle'), and Nematodirus spp. at 2 sites over 2 years. The effects of Trichuris and Monezia spp. infection on weight gains are not shown ${ }^{2}$.

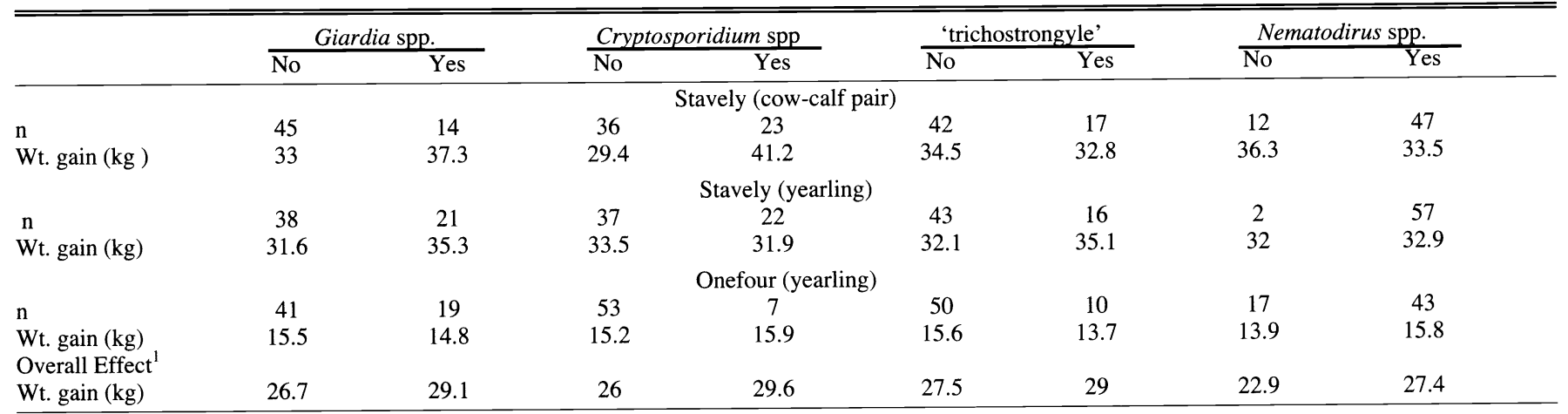

${ }_{1}^{1}$ The effect of infection, or its interaction with site, was not significant $(\mathrm{P}>0.10)$ for any specific parasite.

${ }^{2}$ Trichuris and Monezia spp. were present in 9 and $87 \%$, of all animals, respectively.

biological parameters measured but rather were defined by organic compounds that affected smell or taste (with the possible exception of 1 year at Kamloops when very high levels of $\mathrm{SO}_{4}$ were observed).

The response of cows to water treatments was likely reflected in the weight gains of their calves who receive a major portion of their nutrition from milk. Greater milk production contributes to faster growth in calves but at the expense of the dam (Taylor 1994).

Pumping water and excluding cattle from the pond appeared to produce immediate results over the relatively short period of the study but could conceivably produce more convincing benefits in the longterm. Although the Pond trough $_{\text {treatment }}$ produced results that were most similar to Pond $_{\text {direct }}$, their ranking tended to be intermediate to clean water and Pond direct $_{\text {sug- }}$ gesting that cattle might prefer drinking from a trough and avoid entering the pond. This suggestion is supported by longer grazing times on Pond trough than Pond $_{\text {direct }}$, with the assumption that grazing times are positively correlated with water consumption. Calves seemed to benefit the most by exclusion from the pond although their performance is also linked to their dams. Excluding cattle from direct access to the pond could be expected to produce greater benefits over the longterm through improved water quality as direct fouling is halted and the riparian vegetation is allowed to recover and filter nutrients.

\section{Proposed mechanism of cattle response}

The detrimental effect of pond water on weight gains of cattle appears to be mediated through feed intake rather than by stress induced by pathogens, toxins, or parasites. Cattle that drank clean water spent longer time grazing and, in penned studies, ingested more feed. Therefore, the proposed mechanism to explain weight gain response to water source appears to be defined by the palatability of water that influences water and forage consumption. Pond water was less palatable than clean water, which resulted in less water and feed intake and reduced animal performance. While the trends for average drinking times (Table 4) did not support the contention that more clean water was consumed than pond water $(P>0.10)$, the discrepancy may be explained by variable rates of water intake, among treatments, defined by palatability. However, the hypothesis that intake rates are affected by palatability needs to be tested. In at least 1 year at Kamloops, a high $\mathrm{SO}_{4}$ content appeared to be responsible for reduced weight gains.

Water intake from ponds and feed intake from pastures were not measured but the greater time spent grazing by cattle having clean water suggests greater feed intake as the forage characteristics among paddocks were similar at each site. The relationship

Table 6. Water selection by 2 yearling steers in relation to contamination with fresh manure over the duration of the trial $(n=4)^{1}$.

\begin{tabular}{|c|c|c|c|c|c|c|c|}
\hline \multirow[t]{2}{*}{ Manure conc. } & \multicolumn{7}{|c|}{ Days from trial initiation } \\
\hline & 1 & 2 & 3 & 4 & 5 & 6 & 7 \\
\hline$\left(\mathrm{mg} \cdot \mathrm{g}^{-1}\right.$ water $)$ & \multicolumn{7}{|c|}{ 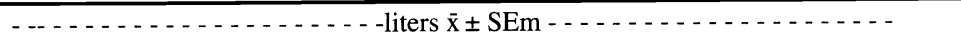 } \\
\hline 0 & $68(24)$ & $124(12)$ & $106(32)$ & $118(14)$ & $116(14)$ & $102(19)$ & $86(10)$ \\
\hline 0.05 & $53(27)$ & $13(12)$ & $27(22)$ & $19(12)$ & $16(9)$ & $22(18)$ & $38(10)$ \\
\hline 0.25 & $1(1)$ & $0(0)$ & $8(5)$ & $4(2)$ & $10(3)$ & $21(6)$ & $16(4)$ \\
\hline Effect $(\mathrm{P})$ & 0.138 & $<0.001$ & 0.047 & 0.001 & $<0.001$ & 0.017 & 0.003 \\
\hline Comparisons & \multicolumn{7}{|c|}{ - } \\
\hline 0 vs 0.05 & $>0.10$ & 0.001 & 0.095 & 0.002 & 0.002 & 0.025 & 0.014 \\
\hline 0 vs 0.25 & 0.071 & 0.002 & 0.054 & 0.004 & 0.004 & 0.021 & 0.003 \\
\hline 0.05 vs 0.25 & $>0.10$ & $>0.10$ & $>0.10$ & $>0.10$ & $>0.10$ & $>0.10$ & $>0.10$ \\
\hline
\end{tabular}

${ }^{1}$ The interaction of treatment $\mathrm{x}$ day was significant $(\mathrm{P}=0.004)$ between water consumption and feed intake has been established (Hyder et al. 1968). The fluid matrix within the rumen plays a key role in facilitating microbial attachment to feed particles and their subsequent digestion (McAllister et al. 1994). Butcher et al. (1959) reported a ratio of 3 liter water for each $\mathrm{kg}$ dry matter of feed consumed when the temperature was about $5^{\circ} \mathrm{C}$ and 7 liter when the temperature was $32^{\circ} \mathrm{C}$. Utley et al. (1969) reported a reduction in feed intake from 6.2 to $4.8 \mathrm{~kg} \mathrm{day}^{-1}$ when water was restricted to $60 \%$ of free choice. The ratios of water to feed also decreased from 2.9 to 2.2 liter $\mathrm{kg}^{-1}$. In the present study, the ratios averaged 3.8 and 4.3 liter $\bullet \mathrm{kg}^{-1}$ in Trials 1 and 2 , respectively. However, the response of feed intake to water consumption, defined by the regression coefficients of the equations, was considerably greater in Trial 1 conducted when the average daily temperature was lower than during Trial 2 (13.6 vs $16.1^{\circ} \mathrm{C}$, data not shown) and thereby imposing relatively greater demands for cooling than for rumen function. than in 2 ( 6 vs 25 liter $\left.\bullet \mathrm{kg}^{-1}\right)$. Trial 1 was 
Table 7. Effect of manure-contaminated water, at a high and low range of concentrations, on water and feed consumption by 2 yearling steers over 2 consecutive, 5-day periods $(n=4)$.

\begin{tabular}{|c|c|c|c|c|}
\hline Manure conc. & water & feed & water & feed \\
\hline$\left(\mathrm{mg} \bullet \mathrm{g}^{-1}\right.$ water $)$ & \multicolumn{2}{|c|}{ Conditioning period } & \multicolumn{2}{|c|}{ Test period } \\
\hline Trial 1 (low) & (liters) & $(\mathrm{kg})$ & (liters) & $(\mathrm{kg})$ \\
\hline 0 & 110 & 28 & 127 & 33 \\
\hline 0.05 & 112 & 29 & 119 & 33 \\
\hline 0.15 & 112 & 30 & 127 & 34 \\
\hline 0.45 & 116 & 30 & 128 & 34 \\
\hline SEM & 6 & 1.1 & 4 & 0.7 \\
\hline Effect (P): & $>0.10$ & $>0.10$ & $>0.10$ & $>0.10$ \\
\hline \multicolumn{5}{|l|}{ Trial 2 (high) } \\
\hline 0 & 152 & 30 & 154 & 32 \\
\hline 2.5 & 123 & 31 & 148 & 31 \\
\hline 5.0 & 107 & 30 & 113 & 30 \\
\hline 7.5 & 112 & 27 & 124 & 28 \\
\hline SEM & 13 & 0.5 & 5 & 0.8 \\
\hline Effect $(\mathrm{P})$ : & $>0.10$ & 0.022 & 0.003 & 0.068 \\
\hline \multicolumn{5}{|l|}{ Comparisons: } \\
\hline 0 vs 0.25 & $>0.10$ & $>0.10$ & $>0.10$ & $>0.10$ \\
\hline 0 vs 0.50 & 0.046 & $>0.10$ & 0.001 & $>0.10$ \\
\hline 0 vs 0.75 & 0.073 & 0.009 & 0.005 & 0.013 \\
\hline 0.25 vs 0.50 & $>0.10$ & $>0.10$ & 0.002 & $>0.10$ \\
\hline 0.25 vs 0.75 & $>0.10$ & 0.006 & 0.021 & 0.083 \\
\hline 0.45 vs 0.75 & $>0.10$ & 0.027 & $>0.10$ & $>0.10$ \\
\hline
\end{tabular}

\section{Potential palatability factors}

The specific compounds responsible for reducing water palatability are unknown although Dohi et al. (1999) identified organic fractions in cattle feces that appear to be responsible for causing avoidance. It is purely speculative that these fractions were also present in pond water. However, cattle were observed to walk into the pond to drink and often defecated while standing in the water. Of 78 observed drinking incidences by cows at Stavely $26 \%$ resulted in defecation into the pond (Data not shown).

Assuming an animal produces $25 \mathrm{~kg}$ manure fresh weight daily, defecates 10 times a day, and defecates $25 \%$ each time it drinks from the pond (on average of twice a day), each animal would then contaminate an equivalent volume of 25,000 $\mathrm{L}$ per day with $0.05 \mathrm{mg}$ fresh manure $\bullet$ grams $^{-1}$ water. This is further aggravated within the pond environment by repeated contamination in the shallow part of the pond. Cattle would avoid this concentration of manure if given a choice of clean water (Table 6).

The role of algae in affecting cattle performance in this study is unclear but might contribute to reduced palatability and can be toxic. The effect of algae on water palatability has not been tested but the toxicity of some species to cattle has been clearly established. Symptoms in cattle are weakness, variable hyperthermia, reduced responsiveness, anorexia, mental derangement, shock, and death (Beasley et al. 1989). While lethargy may be an early symptom of toxicity, and might explain reduced grazing and greater resting times of animals drinking from the pond, algae densities did not appear to affect performance. For example in 1997 at Stavely, yearling cattle performed similarly while drinking pond water directly or from a trough (Table 3) although algae densities in the trough were only about $25 \%$ of the density in the pond (Table 2). Similar evidence exists in 1998 at both Onefour and Kamloops when algae densities were above average and varied between water treatments, but weight gains of cattle between treatments were similar.

Salt concentrations in water were clearly implicated as a factor affecting cattle weight gains at Kamloops in 1998 when $\mathrm{SO}_{4}$ concentrations greatly exceeded 8,000 $\mathrm{mg} \bullet$ liter $^{-1}$, a concentration that depressed water intake by $20 \%$ (Embry et al. 1959). Cattle drinking pond water had diarrhea and displayed symptoms of salt overload. Salt concentrations in the pond water are determined by recharge and evaporative losses. As a result, concentrations tend to increase over the summer and vary among years in relation to the weather.

\section{Conclusion}

Clean water is essential for maximizing cattle weight gains on rangeland in summer. Over a 2 -month period, yearling cattle gained $23 \%$ more weight when drinking clean water than drinking directly from a pond and $20 \%$ more than drinking pond water pumped to a trough. Calves with dams gained $10 \%$ more weight. It is not clear how these effects would translate to the production cycle of cattle through compensatory growth and different water sources as the animals' environment will change. For producers that sell their cattle in fall, the opportunity for benefitting from potential compensatory gains is clearly lost to the buyer.

The study raises a number of questions that need to be addressed in further research. One is on compensatory growth as discussed above. A second question is on the secondary effects of preventing direct access on water quality and the riparian environment. Here the specific issues are on the nature and stability of anti-palatability factors in water and the function of riparian zones. The nature of exclusion itself needs to be examined as ranchers are unwilling to fence off the pond from cattle in the event of a pump failure. Therefore, the third question is on the effectiveness of offering water offsite in preventing direct access to the pond and damage to the riparian zone. Finally, the fourth question is on the application of the results to non-pasture environments such as feedlots where cattle are subject to an environment with high manure concentrations.

\section{Literature Cited}

Anderson, B.C. 1991. Prevalence of Cryptosporidium muris like oocysts among cattle populations of the United States. A preliminary report. J. Protozool. 38:148-152.

Barrio, J.P., S.T. Bapat, and J.M. Forbes. 1991. The effect of drinking water on foodintake responses to manipulation of rumen osmolality in sheep. Proc. Nutr. Soc. 50:98A.

Beasley, V.R., W.O. Cook, and A.M. Dahlhem. 1989. Algae intoxication in livestock and waterfowl. Vet. Clinics North Amer. 5:345-361.

Butcher, J.E., L.E. Harris, and R.J. Raleigh. 1959. Water requirements for beef cattle. Utah Farm and Home Sci. 20:72-73.

Canadian Council of Ministers of the Environment. 1999. Canadian environmental quality guidelines. Canadian Council of Ministers of the Environment, Winnipeg, Canada.

Crawford, R., E. Cole, and J. Carpenter. 1996. Effect of water source and quality on water intake and performance of steers grazing tall fescue. Pages 15-18 In: 1996 Research Report, Southwest Missouri Agricultural Research and Education Centre, Mo. Agr. Exp. Sta., Mt. Vernon, Mo.

Clesceri, L.S., A.E. Greenberg, and R.R.Trussell. 1989. Standard Methods for the Examination of Water and Wastewater. Amer. Publ. Health Assoc., Wash., D.C. 
Cox, D.D. and A.C. Todd. 1962. Survey of gasterointestinal parasitism in Wisconsin dairy cattle. J. Amer. Vet. Med. Assoc. 141:706-709.

Coupland, R. T. 1961. A reconsideration of grassland classification in the Northern Great Plains of North America. J. Ecol. 49:135-167.

Dohi, H., S. Ogura, T. Kosako, Y. Hayashi, A. Yamada, and S. Shioya. 1999. Separation of deterrents to ingestive behavior of cattle from cattle feces. J. Anim Sci. 77:756-761.

Embry, L.B., M.A. Hoelscher, R.C. Wahlstrom, C.W. Carlson, L.M. Krista, W.R. Brosz, G.F. Gastler, and O.E. Olson. 1959. Salinity and livestock water quality. S. Dak. Agr. Sta. Bul. 481.

Holechek, J.L. 1980. The effects of vegetation type and grazing system on the performance, diet and intake of yearling cattle. Ph.D. Thesis, Oregon State Univ., Corvallis, Ore.

Hyder, D.N., R.E. Bement, and J.J. Norris. 1968. Sampling requirements of the waterintake method of estimating forage intake by grazing cattle. J. Range Manage. 21:392-397.
Ingram, W.M. and B.W. Prescott. 1954. Toxic fresh-water algae. Midl. Nat. 52:75-87.

McAllister, T.A., H.D. Bae, G.A. Jones, and K.-J. Cheng. 1994. Microbial attachment and feed digestion in the rumen. J. Anim. Sci. 72:3004-3018.

Olson, M.E., T.A. McAllister, L. Deselliers, D.W. Morck, K-J Cheng, A. Buret, and $\mathrm{H}$. Ceri. 1995. Effects of giardiasis on production in a domestic ruminant (lamb) model Amer. J. Vet. Res. 56:1470-1474.

Olson, M.E., C.L. Thorlakson, L. Deselliers, D.W. Morck, and T.A. McAllister. 1997b. Giardia and Cryptosporidium in Canadian farm animals. Vet. Parasitol. 68:375-381.

Olson, M.E., N.J. Guselle, R.M. O'Handley, M.L. Swift, T.A. McAllister, M.D. Jelinski, and D.W. Orck. 1997a. Giardia and Cryptosporidium in dairy calves in British Columbia. Can. J. Vet. 38:703-706.

Palmer, C. M. 1959. Algae in Water Supplies. U.S. Department Health, Education and Welfare, Public Health Service, Div. of Water Supply and Pollution Control. Washington D.C.
SAS Institute Inc. 1999. SAS/STAT Users Guide. Version 8. SAS Institute Inc., Cary, N.C.

Taylor, R.E. 1994. Beef Production and Management Decisions, $2^{\text {nd }}$ Edition, Macmillan Publishing Company, N.Y.

Utley, P.R., N.W. Bradley, and J.A. Boling. 1969. Effect of restricted water intake on feed intake, nutrient digestibility and nitrogen metabolism in steers. J. Anim. Sci. 31:130-135.

Weeth, H.J. and J.E. Hunter. 1971. Drinking of sulphate water by cattle. J. Anim. Sci. 32:277-281.

Weeth, H.J. and D.L. Capps. 1972. Tolerance of growing cattle for sulfate water. J. Anim. Sci. 34:256-260.

Xiao, L., R.P. Herd, and K.E. McClure. 1994. Periparturient rise in the excretion of Giardia sp. cysts and Cryptosporidium parvum oocysts as a source of infection for lambs. J. Parasitol. 80:55-59. 